\title{
PSYCHE.
}

\section{THE INSECTS OF BETULA IN NORTH AMERICA.}

BY ANNA KATHERINA DIMMOCK, CAMBRIDGE, MASS.

My attention was first drawn to the number of insects which feed upon plants of the genus Betula when I set out to make a collection illustrating the different stages of insects found on $\mathrm{Be}$ tula alba. I had exhibited stages of 39 determined species, and intended to publish a simple list of these, but so many additions to the list were found later in scattered publications that further notes were added. Finally, after the publication of Dr. G: Dimmock's "Notes on pterophoridae of North America," I determined to put the notes in the form adopted in that article, and to include the American insects of the entire genus Betula. The notes have steadily increased in bulk, until they now include Io7 determined species. This number would be still further augmented by the determination of several species which I have reared from Betula alba. Kaltenbach ${ }^{2}$ gives 27 o European birch-feeding insects, and where the same species of insects are found in Americal I have added them to

\footnotetext{
i Psyche, Sept.-Oct. 1882, v. 3, p. 402-404.

2 Kaltenbach, J. H. Die pflanzenfeinde aus der classe der insecten. Stuttgart, 1874 .
}

this list. Packard ${ }^{3}$ enumerates only 19 species of American insects from Betu$l a$. The numerous bibliographical references here included, which were selected from those accumulated in the progress of my work, refer generally to easily accessible works and are not inappropriate in a bibliographical journal like Psyche. Most of the citations have been verified,--a few are quoted. For many of them and for the free use of notes I am indebted to my husband, Dr. G : Dimmock. We have for several years reared and studied insects together, and some of the larvae mentioned in this article will be described by him later. My thanks are due further to Prof. C: H : Fernald, Dr. S : W. Williston, and Messrs. S: Henshaw and R. Thaxter, for identifying insects belonging respectively to the microlepidoptera, diptera, coleoptera, and macrolepidoptera.

Quite extended lists of food-plants have been compiled in the case of certain lepidoptera, because these insects are often reared for pleasure, and because an accurate knowledge of foodplants is desirable, even for polyphag-

3 Bull. 7, U. S. entom, comm., Washington, 1881 . 
ous species. Here it might be added that Betula alba is very useful in rearing certain polyphagous species, since its leaves remain in good condition for a long time, and are the favorite food-plant of many insects. Certain polyphagous species, as Attacus cecropia, do not feed readily on other foodplants after having eaten birch. Larvae (especially of geometridae) of which the food-plant is unknown, can often be reared successfully on Betula alba, a fact to which I owe my successful rearing of Endropia armataria.

\section{Orthoptera.}

Phaneroptera curvicauda De Geer (Mém. hist. ins., I773, v. 3 , p. 446 , pl. 38 , fig. 3 ). This species has been figured, together with the structure of its ovipositor, by Riley (6th rept. state entom. Mo., I874, p. I64-I66), who also gives descriptions of the younger stages, and eggs. Miss Murtfeldt (l. c.) describes the mode of oviposition : the eggs are laid in the margin of leaves-often of oak-between the upper and lower epidermis. Altho Riley writes (l. c.), "I have had as many as five of these eggs deposited in a single leaf, in one contiguous row, yet they are more often single," yet a single tender leaf of $\mathrm{Be}$ tula alba, taken at Belmont, Mass., measuring about $8 \mathrm{~cm}$. in length, had the entire margin filled with eggs, presumably of this species. Only two or three leaves were found thus attacked, and the one of which the size is given above contained 102 eggs.

Caloptenus femur-rubrum De Geer (Mém. hist. ins., I773, v. 3, p. 498, pl. 42, fig. 5) often strips the leaves from low bushes of Betula alba about Cambridge, Mass.

\section{RHYNCHOTA.}

Eriosoma tessellata Fitch (4th ann. rept. [N. Y.] state cab. nat. hist., I85I, p. 68). According to Glover (Rept. U. S. commiss. agric., 1876, p. 39) this species has been found in Maryland upon twigs of Betula.

Callipterus betulaecolens Riley and Monell (Bull. U. S. geol. and geog. surv. terr., I879, v. 5 , p. 30-3r) $[?=$ Aphis betulaecolens Fitch (4th ann. rept. [N. Y.] state cab. nat. hist., r85 r, p. 66)]. Said by Fitch and Monell to feed on birch leaves.

Calaphis betulella Walsh (Proc. Entom. soc. Phil., Dec. I862, v. I, p. 3OI-302). Walsh ( $l$. c., p. 302) says this species is abundant in Illinois on Betula nigra.

Athysanus variabilis Fitch (4th ann. rept. [N. Y.] state cab. nat. hist., $185 \mathrm{I}, \mathrm{p} .60)$ is stated by Fitch $(l . c$.$) to be "abundant on$ birch trees, in June," and the same author states (Ann. rept. N. Y. state agric. soc., I 858 , v. . 8, p. 853 ) that this species punctures leaves and succulent shoots of birch. A brief description of this insect is given by Packard (Bull. 7, U. S. entom. comm., I881, p. I28).

Athysanus abietis Fitch (4th ann. rept. [N. Y.] state cab. nat. hist., 1851, p. 6o) is stated by Fitch (Ann. rept. N. Y. state agric. soc., 1857 , v. I7, p. 749) to feed on birch. Packard (Bull. 7, U. S. entom. comm., I88I, p. 235) briefly describes the species and gives Betula as food-plant.

Athysanus minor Fitch (4th ann. rept. [N. Y.] state cab. nat. hist., I 85 I, p. 6o). Fitch (l. c.) writes "Common on birch trees," and adds (Ann. rept. N. Y. state agric. soc., I858, v. I8, p. 853) that it punctures birch leaves. Packard (Bull. 7, U. S. entom. comm., r88r, p. I28) briefly describes this species.

Athysanus fenestratus Fitch (4th ann. rept. [N. Y.] state cab. nat. hist., $185 \mathrm{I}, \mathrm{p} .60)$ is stated by Fitch ( $l . c$.) to be found "on birch trees," and (Ann. rept. N. Y. state agric. soc., I858, v. 18, p. 853) to puncture birch leaves. This species is briefly described by Packard (Bull. 7, U. S. entom. comm., r88r, p. r28).

Thelia univittata Harris ('Treatise on ins. injur. veg., I842, p. I80). One specimen taken sucking juices of a twig of Betula alba, June 1884 . This species is found on oak, ac- 
cording to Harris $(l . c$.$) , where it is common$ in July, according to Packard (Bull. 7, U. S. entom. comm., r88r. p. 37).

Enchenopa binotata Say (Appendix Long's exped., I824, p. 30I-302). Common on twigs of Betula alba. Riley (Amer. entom., Aug. I869, v. I, p 248) says its favorite home is Ptelea trifolium, but gives grape (Vitis) and red-bud (Cercis) as food-plants. Its egg is described in Amer. entom., Oct. 1880, v. 3, p. 254. Lintner (Ist ann. rept. state entom. N. Y., r882, p. 28r-288) gives an excellent general account of imago and eggs, both of which are figured. As food-plants he adds Celastrus scandens and, upon the authority of others, Fuglans and Robinia.

Bythoscopus seminudus Say (Journ. Acad. nat. sci. Phil., I829 [Mch. I83I], v. 6, p. 307). Fitch (4th ann. rept. [N. Y.] state cab. nat. hist., I $85 \mathrm{I}$, p. 58) writes "Found on birch trees."

Tingis juglandis Fitch (Ann. rept. N. Y. state agric. soc., 1856 , v. 16, p. $466-467$ ) is normally found, according to that author (l. c.) on Fuglans cinerea, but is sometimes met with also on Betula, Salix, and other trees. Packard (Bull. 7 , U. S. entom. comm., 188I, p. 88) briefly describes this species, and mentions its food-plants.

\section{Dipte:RA.}

Mallota posticata Fabr. (Syst. antl., r805, p. 237). Packard (Guide study ins., I 869, p. 399) figures the pupa and imago of this species under the name of Merodon bardus Say. Lintner (Ist ann. rept. state entom. N. Y., I882, p. 211-216) gives an extended account of this insect, figuring the puparium and imago, and describing the larvae, which were taken from decaying birch wood.

Lonchaea epolita Say (Journ. Acad. nat. sci. Phil., I830, v. 6, p. 188). Reared in Cambridge, Mass.. from decaying Polyporus betulinus, a fungus parasitic on dead runks of Betula alba.

\section{LEPIDOPTERA.}

Argyresthia goedartella Linn. (Syst. nat., I758, ed. Io, p. 897). Fabricius (Syst. entom., I775, p. 664) writes of this species "Habitat in alnetis, in betulae gemmis," and Kaltenbach (Planzenfeinde, I872, p. 604-605) states that the larvae of this species live in the catkins of Betula and Alnus. Chambers (Can. entom., Aug. 1875, v. 7, p. I44-145) notes the discovery of this species in North America, and, atter describing the imago, adds "The larva feeds under the bark and in the young shoots of the birch in March and April." A. Balding (Entom. monthly mag., Feb. I885, v. 21, p. 203-206) describes the larva, which he found feeding in catkins of Betula and Alnus.

Cryptolechia confertella Walk. (List lep. ins. Brit. mus.. I864, pt. 29, p. 563). The larvae of this species are common upon $B e$ tula alba during August and the early part of September. The larva feeds in a rolled portion of the margin of the leaf, where pupation takes place, lasting from three weeks to a month.

Paedisca similuna Hübn. (Samml. auserl. vögel u. schmett., I792, fig. $7 \mathrm{I}$ ). Kaltenbach (Pflanzenfeinde, 1872, p. 602) gives a very brief description of the larva of this species, which feeds upon Betula.

Paedisca transmissana Walk. (List lep. ins. Brit. mus., 1863, pt. 28, p. 375). The larva of this species is common, during October, about Cambridge, Mass., where it eats out the inside of the sterile catkins of Betula alba. It hibernates as pupa.

Paedisca solicitana Walk. (List lepid.ins. Brit. mus., I863, pt. 28, p. 387). Fernald (Trans. Amer. entom. soc., r882, v. Io, p. 40) says of this species "Food.-Betula alba var. populifolia."

Sericoris urticana Hübn. (Samml. europ. schmett., Tort., 180o?, fig. 65). Kaltenbach (Pflanzenfeinde, 1872 , p. 6or) gives a very brief description of the larva, following Zeller (Isis, 1846, p. 229) and among other foodplants mentions Betula. 
Penthina albeolana Zeller (Verhandl. k.-k zool.-bot. gesell. Wien., jahrg. $1875, \mathrm{I} 876$, bd. 25 ; Abh., p. 262-263, pl. 8, fig. 12). A single larva taken 4 Sept. 1882 , at Cambridge, Mass., on Betula alba, pupated 6 Sept., and appeared as imago 24 May 1883. This species is evidently two-brooded, as Burgess took the specimen from which Zeller described the species, on ${ }_{5}$ Aug., in Massachusetts.

Penthina dimidiana Sodoffsky (Bull. Soc. impér. natur. Mosc., I 830 , v. 2, p. 73, pl. 7). Kaltenbach (Pflanzenfeinde, 1872, p. 615) briefly describes the larva of this species, which feeds upon Betula and on several other plants.

Penthina capreana Hübn. (Samml, europ. schmett., Tort., 1800?, fig. 250). Kaltenbach (Pflanzenfeinde, I872, p. 60I) compiles a brief description of the larva of this species, which feeds upon Betula and Salix.

Eccopsis ?var. of permundana Clemens (Proc. Acad. nat. sci. Phil., r86o, p. 356-357). Two specimens reared from larvae taken in Cambridge, Mass., I7 June 1883 , on Betula alba. Pupated about 30 June; one specimen emerged as imago io July and the other $\mathrm{I}_{5}$ July i883. Clemens (l.c.) says of E. permundana, "The larva binds together the terminal leaves of Spiraea. It is pale green, touched with yellowish at the junction of the segments; head and shield black. The larva may be taken in the middle of June."

Eccopsis zelleriana Fernald (Trans. Amer. entom. soc., I882, v. Io, p. 29) is said by its describer to feed upon "Leaves of Betula alba var. populifolia."

Lozotaenia musculana Hübn. (Samml. europ. schmett., Tort., I80o?, fig. 98). Kaltenbach (Pflanzenfeinde, I872, p. 6o1) quotes Madame Lienig's description of the larva of this species, and states that the larvae, according to Fischer von Röslerstamm, feed between leaves of Betula and Salix which they have drawn together. Fernald (Trans. Amer. entom. soc., I882, v. 10, p. I3) says, "Food.-In Europe, Agrimonia, Genista, Solidago, Achillea, Stachys, Scrophularia,
Rubus, Betula, Salix, Galium, 2uercus, Pyrus and Tilia."

Cacoecia cerasivorana Fitch (Ann. rept. N. Y. state agric. soc., 1856, p. 382, pl. 2, fig. 3). Fernald (Trans. Amer. entom. soc., I882, v. Io, p. II) writes of this species, "Food.- Cherry, Betula alba var. populifolia."

Cacoecia rosaceana Harris (Rept. ins. injur. veget., I84I, p. 348). Harris (op. cit., p. $347-348$, and op. cit., i862, p. 480) describes the larvae of this species. Description and figure of larva and imago by Packard (Guide study ins., i869, p. 335, pl. 8, fig. 12). Description of larva, with figure of larva, pupa, and imago, by Saunders (Ann. rept. Entom. soc. Ontario, 1873, p. I4). Packard (Papilio, Nov.-Dec. I882, v. 2, p. I82-I83) says that he has reared this species from Betula alba var. populifolia, the moth appearing, in Maine, on the first of September. Coquillett (Papilio, May-June I883, v. 3 , p. IOO-IOI) describes the larva carefully and gives the names of twenty-four species of food-plants. To his list may be added Viburnum dentatum and Philadelphus coronarius.

Teras ferrugana Schiffermüller (Syst. verz. d. schmett. d. Wiener gegend, I776, p. I28). Kaltenbach (Pflanzenfeinde, I872, p. $600)$ says, on authority of Treitschke, that this species feeds on Betula and more rarely on Populus and Alnus; Fernald (Trans. Amer. entom. soc., I882, v. Io, p. 9), on authority of Heinemann, adds 2uercus, and cites Walsh for authority that the species is inquilinous in galls of Cynips salicis-strobiloides. Packard (Papilio, Nov.-Dec. I882, v. 2, p. I82) reared the species from a larva swept from Pinus strobus, on which he thinks the larvae feed, and gives a description of larva and pupa.

Teras niveana Fabr. (Mant. insect., 1787 , v. 2, p. 233). Kaltenbach (Pflanzenfeinde, I $87^{2}$, p. 600) says, on authority of Anton Schmid, that the larva of this species lives on Betula. 
Several species of microlepidoptera which are still undetermined are very abundant on Betula alba, about Cambridge, Mass. Among them may be mentioned a case-bearer (? Coleophora), a species having a ridged cocoon (? Bucculatrix), a species the larva of which has a case made of successive rings of leaf-epidermis arranged in the form of a cornucopia, and a large leaf-miner belonging to some genus allied to Lithocolletis; the larvae of the last two species are found very late in the season, just before the leaves are destroyed by the frost.

Operophtera boreata Hübn. (Samml. europ. schmett., Spanner, I796, fig. 413-4I4). Kaltenbach (Pflanzenfeinde, 1872 , p. 599) gives Betula and Fagus as food-plants of this species. Packard (Mon. geom. moths, 1876 , p. 199) quotes Newman's description of the larva of this species.

Rheumaptera hastata Linn. (Syst. nat.,
I758, ed. 10, p. 527). Schmiedlein (Naturges. deutsch. schmett., 1805 , p. IOI-IO2) describes the larvae of this species, which he states live socially upon birch between the leaves which they spin together. Packard (Mon. geom. moths, I876, p. 165-166) quotes Newman's description of the larva, in which it is stated to feed upon Betula alba and Myrica gale. Kaltenbach (Pflanzenfeinde, 1872 , p. 4I 3 and 599) compiles authorities for the following additional food-plants of this species: Rhododendron hirsutum, Salix, and Vaccinium uliginosum. A larva of this species, taken on Betula alba, at Belmont, Mass., 4 Aug. I883, pupated I4 Aug., and appeared as imago 17 May 1884. This is one of the species of lepidoptera seen in swarms in parts of the White Mts., N. H., where specimens were taken from 8-I4 July 1874 in the greatest abundance.

( $T o$ be continued.)

\section{SYSTEMATIC POSITION OF THE GENUS APIOCERA.}

BY DANIEL WILLIAM COQUILLETT, ANAHEIM, CAI.

In the Berliner entom. zeitschrift for 1883, p. 287-294, Baron Osten Sacken gives his reasons for placing the genus Apiocera among the asilidae. I am strongly of the opinion, however, that its proper place is among the therevidae-an opinion which the following facts would appear to fully justify.

In the Monographs of the diptera of North America, part 1, p. 22 and p. 24, Dr. Loew defines the families asilidae and therevidae in the following words:

"Asilidae.-Three basal cells much prolonged. Third longitudinal vein of the wings furcate, the two intercalary veins always present. Third joint of the antennae simple; under lip forming a horny sheath; empodium similar to a horny bristle."

"Therevidae.--Three basal cells much prolonged; the two intercalary veins present; third longitudinal vein furcate. Antennae with a terminal style of variable form, sometimes wanting. No empodium. Under lip fleshy."

In many of the larger therevidae the empodium, or third pulvillus, is present in the form of a slender bristle. The only character of importance, therefore, whereby either of these families may be distinguished from the other is the structure of the under lip or proboscis, which 

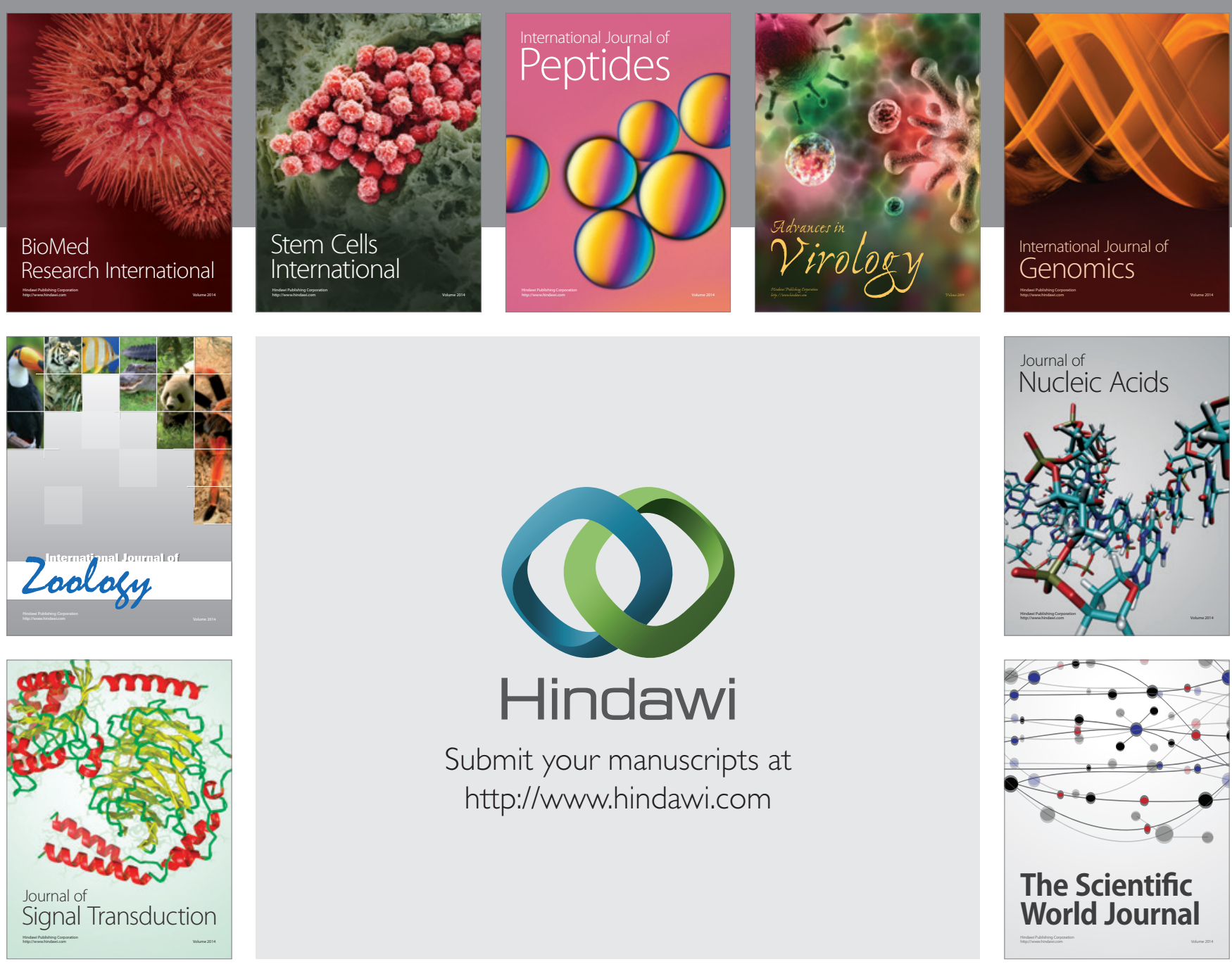

Submit your manuscripts at

http://www.hindawi.com
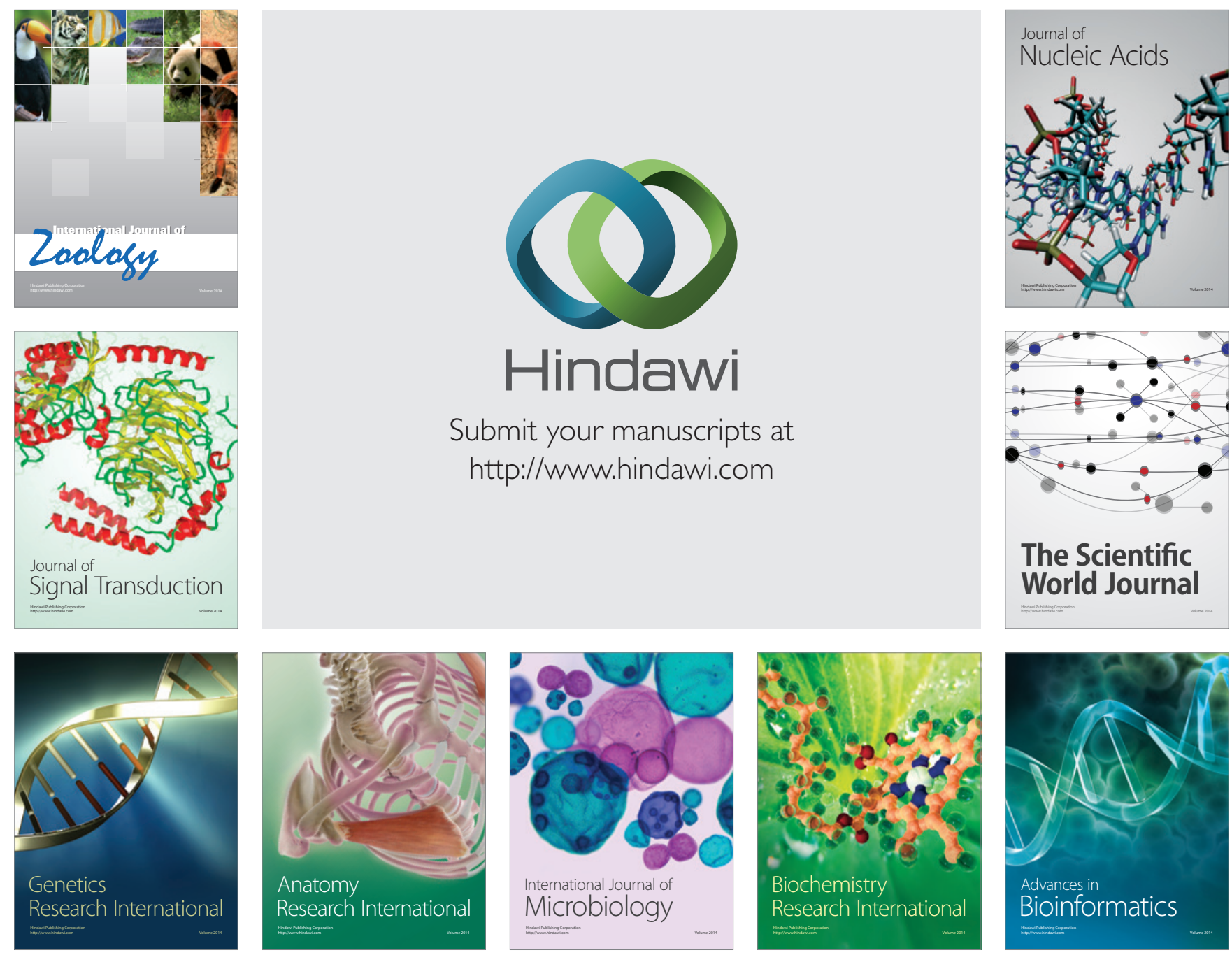

The Scientific World Journal
